\title{
Trends in the Study of the Comparative Endocrinology of Reproduction in Vertebrates ${ }^{1}$
}

\author{
G. J. VAN OORDT \\ Zoological Laboratory, Department of Endocrinology, University of Itrecht, \\ The Netherlands
}

\section{INTRODUCTION}

A couple of months ago the organizers of the present Conference asked me to deliver an opening address, which would review the development of comparative endocrinology in Europe, particularly with reference to my own work and experiences. Of course I accepted this invitation with very much pleasure; nevertheless I made one objection: the original theme would take too much time. Thus, I will only speak about spectacular discoveries in the endocrinology of sex in Vertebrates, a subject about which I have witnessed amazing development during the past four decades and to which my co-workers and I have contributed some new facts. Consequently my address will bear a very personal character.

\section{CASTRATION- AND GONAD-TRANS- PLANTATION EXPERIMENTS}

When surveying the development of the endocrinology of sex, I have to go back, strietly speaking, to 1849 . In this year, Berthold concluded from his experiments on autotransplantation of testes in cocks, that the influence which the male gonad exerts on the body is not, as was generally accepted, mediated by the nervous system, but must be ascribed to changes in the blood that runs through the testes.

Berthold's work, however, fell into oblivion, and scientific research into the endocrinology of sex did not begin until the end of the last or the beginning of the present century. As this research was al-

\footnotetext{
${ }^{t}$ Opening address to the Conference of European Comparative Endocrinologists, London, 1962.
}

most exclusively earried out by medical investigators, mammals were mostly chosen as experimental animals; some work, however, was also done with representatives of other Vertebrate classes; among these studies the castration experiments of Steinach $(1894,1910)$ and of Nussbaum (1909) with frogs may be mentioned.

Many scientists are of the opinion that Steinach's well-known papers on heterosexual gonad transplantation in mammals $(1912,1913)$ were the immediate cause of the fact, that after 1913, endocrinological investigation into sex problems became one of the most interesting fields of zoological research. Brilliant work on this subject was then carried out by Pézard, who published during the beginning of the present century (Pézard, 1912, 1918) the results of heterosexual gonad transplantations in the fowl, and who showed inter alia, in experiments in which he obtained "gynandromorph" feathers, how readily the feather-follicles react to the injected hormone (Pézard et al., 1926).

At about the same time Zawadowsky (cf. 1922) stressed the fact that not all secondary sex characteristics are under the influence of the gonads but that some are dependent on the sex hormones, while others are independent of them. For instance, the beautiful permanent male plumage of the cock of our common fowl breeds is an independent characteristic, whereas the simple plumage of the hen is dependent on the ovary. The head-furnishings as well as the male and female behavior and temperament, are, however, dependent characteristics in both sexes.

As field-ornithology has been a hobby of 
mine since my youth and onwards, it was a matter of course that, when planning to carry out castration investigations into birds, I chose wild bird-species as experimental malerial, after some experiments with male and later also with female turkeys (van Oordt and van der Maas, 1929; van Oordt, 1933).

It then turned out that the beautiful periodical breeding dress of the male ruff (Philomachus pugnax) is a dependent sex characteristic (van Oordt and Junge, 1936) and that the summer plumage of the blackheaded gull (Larus ridibundus), a so-called ambosexual characteristic that develops in spring in both sexes, is, as far as the male sex is concerned, dependent on the testes (van Oordt and Junge, 1933). Later Noble and Wurm (1940) found that in the femalc American laughing gull (Larus atricilla), a close relative of our black-headed species, the ambosexual characteristics are dependent on the ovary. Moreover, these workers showed that the development of these characteristics in the female gull is caused by testosterone, secreted by the ovaries, an interesting illustration of the fact that in mammals and in birds the gonads of both sexes secrete male as well as female sex hormones.

\section{SOURCE AND ASSAY OF THE MALE SEX HORMONE}

Another object which has interested me for years is the source of the sex hormone in the Vertebrate testis.

Those of us belonging to the older generation will certainly remember the controversy about the function of the interstitial or Leydig cells of the mammalian testis with Steinach (1912) and Lipschütz (1919) on one side, and Stieve (1921) on the other. Nowadays, we are convinced that these cells are, in mammals and in birds, the producers of the male sex hormone. Amongst the evidence on which this view is based, is the fact that in experimental cryptorchidism the epithelium of the seminiferous tubules of the mammalian testis degenerates, whereas the Lcydig cells remain intact and the sex characteristics show no sign of male hormone deficiency
(Bouin and Ancel, 1903) and that this is also the case after vaso-ligation or exposure to heat. Moreover, the Leydig cells are stimulated by the administration of interstitial cell stimulating hormone (ICSH of LH) or chorion gonadotropin to hypophysectomized mammals and birds, or to young mammals and birds or to birds outside the breeding season. Simultaneously the accessory sex organs and other sex characteristics show excessive development (Sluiter, 1945; Sluiter and van Oordt, 1947, 1949). It is thus an established fact that in homoiothermous Vertebrates the Leydig cells produce and secrete the male sex hormone.

In cold-blooded Vertebrates the problem of the source of the male sex hormone is certainly much more complicated. One reason for this is that it is sometimes difficult or even impossible to establish a correlation between the number or even the presence of Leydig cells and the development of certain sex characteristics [van Oordt (1924), in Gasterosteus]. Further, in some fish-species with well-developed sex characteristics Leydig cells are absent from the testes when these characteristics develop [e.g., in Xiphophorus; van Oordt (1925)]. Recent investigations, however, have shown that the Leydig cells of some cold-blooded Vertebrates have a function similar to that observed in mammals and birds. To obtain further information, cytological investigations with modern techniques are now being carried out (de Kort, unpublished).

In concluding this section on testosterone, it should be recalled that the investigations into the influence exerted by the testes on the head-furnishings of the cock led Gallacher and Koch (1930) and Freud et al. (1932) to devise a method by which the male sex hormone can be assayed. This method makes use of the fact that the growth of the head-furnishings that follows the injection of testosterone into castrated cocks, is a quantitative measure of androgenic activity. In this connection I will also mention the fact that when the testicular hormone was first isolated in purc form from bull testes in 1935 by David et al., the same assay method was used. 


\section{EXPERIMENTAL SEX INVERSION}

One of the milestones of sex-investigation was undoubtedly the explanation of the origin of the freemartin by Keller and Tandler (1916), and independently by Lillie $(1916,1917)$. This was followed by the appearance of many important contributions to the physiology of sex.

In 1923 it was shown by Harms and in 1924 by Ponse that after extirpation of the testes of male toads (Bufo bufo) these animals can change their sex, as their rudimentary ovaries (or Bidder's organs) can then develop into functional ovaries. Moreover, Crew (1923) showed that as a result of a tubercular tumor in the left ovary of a hen the right, rudimentary gonad developed into a testis, and subsequently Benoit (1923), Zawadowsky (1926) and others, among whom especially Domm (1927, 1931) must be mentioned, obtained a complete sex inversion in chickens after excision of the left ovary, the right rudimentary gonad developing into a testis-like organ.

When some years later pure hormone extracts and even synthetic hormones became available, a great number of investigations were carried out with the aim of obtaining complete sex inversion or freemartin phenomena. It would take too long to mention these experiments in detail: it is sufficient to refer here to the work of Dantschakuff (cf. Dantschakoff, 1941), who was the first to obtain freemartin effects in mammals by injecting the hormones into the embryos in utero, and to the experiments of Wolff and Ginglinger (1935), and of Willier et al. (1935) who simultaneously with Dantschakoff published papers in which it was shown that freemartin phenomena can easily be obtained by injecting female sex hormones into genetically male chicken embryos.

Further, Burns (1925, 1930, 1931) and Witschi $(1927,1936)$ succeeded in obtaining sex inversion in parabiotically-united axolotl-larvae, while Humphrey (1928, 1936) obtained the same result following the grafting of gonadal primordia in Amblystoma.

Spectacular results in this field were obtained by Gallien (cf. his survey in 1955 and also 1956): a total and permanent masculinization by treating female larvae of Ranidae with androgens and a comparable feminization in male larvae of Urodeles and of Xenopus by the use of estrogens. Moreover, the sexual functions of these sex inversed amphibians were entirely normal.

Our own work in this field has been very limited; in a study of the influence of dehydroandrosterone on the gonads of sexlinked chicken embryos, derived from a cross between Brown Leghorn cocks and Light Sussex hens, it was shown (van Oordt and Rinkel, 1940) that this hormone has in genetically male embryos the same influence as estrone.

\section{FETAL HORMONES OF REPRODUCTION}

It is generally known that Keller and Tandler (1916) and Lillie (1916, 1917) came to the conclusion that the freemartin is the female fetus of heterosexual cattle twins, and that it has been masculinized by the sex hormone of the male co-twin as a result of the allanto-choria of both fetuses becoming united at an early developmental stage, with the consequent establishment of vascular anastomoses between the two fetuses. Thus, in the freemartin well-developed Wolffian ducts and scrotal sacs may be found, whereas the ovaries are sterilized or may even be converted into testes (Willier, 1921). This implies that the male fetus secretes its sex hormone prior to the secretion of the female embryological sex hormone, and that accordingly only the female fetus is affected.

Consequently, the explanation of the development of the bovine freemartin postulates the existence of fetal sex hormones, a hypothesis which has, however, been strongly criticized by Moore (1943, 1947) who castrated juvenile opossums which, being still in possession of many fetal characteristics, had very recently entered the marsupial pouch. Moore failed to find any change in his experimental animals, and on this ground he denied the existence of fetal sex-hormones.

Some years later, however, Jost (1947, 
cf. also 1961) proved by castration experiments that the testis of the rabbit embryo does undoubtedly secrete a hormone. $\mathrm{He}$ showed that, if male rabbit embryos were castrated in utero before day 21 of pregnancy, the Wolffian ducts and the structures developing from them did not develop. If, however, the operation was carried out after day 24 , then it had no effect. Moreover, Wells (1947, cf. 1959) obtained a distinct reduction in the number of interstitial cells of rat fetuses, following pituitary gland deprivation by decapitation, thus showing that in the fetal rat a gonadotropic action is also present.

\section{DISCOVERY OF FEMALE SEX HORMONES}

A paper, which was the basis of extremcly important progress in the study of the endocrinology of reproduction in mammals, was that of Stockard and Papanicolaou (1917). These authors described the differences in vaginal smear of estrous and non-estrous guinea-pigs, and were able to correlate changes in the vaginal epithelium with phases of the ovarian cycle. This correlation made it possible to assay the estrogenic activity of ovarian extracts, and led to Edgar Allen and Doisy's discovery (1923) of an ovarian substance which was able to change the epithelium of the vagina of a castrated rat into the estrous condition.

The interest which was aroused by the finding of this first ovarian hormone delayed biochemical investigations into the second mammalian female sex hormone, progesterone, and it was some years before Corner and Willard M. Allen (1929) prepared an extract from hog corpora lutea that caused the endometrium to pass over from the proliferation phase into the secretion phase.

Having mentioned the mammalian corpora lutea I will now briefly discuss the nature of the pre-ovulation corpora lutea, which are of wide occurrence in fish, and were described for the first time in the bitterling (Rhodeus amarus) by Bretschncider and Duyvenć de Wit (1941). These workers were of the opinion that the pre-ovulation corpora lutea secrete a hor- mone, the so-called ovoductin, under the influence of which the ovipositor of the bitterling lengthens. Though some authors, for instance D'Ancona (1950) and Hoar (1955), agree with the concept that the pre-ovulation corpus luteum has a secretory function, the nature of its hormone has never been traced. According to some investigators these structures are merely corpora atretica without endocrine function.

\section{PROLACTIN}

As we all know the techniques employed in comparative endocrinological investigations are more or less similar to those used in mammalian endocrinology; in most cases they have been applied in mammals long before comparative endocrinologists began to use them with other vertebrates as experimental animals. Consequently, the results obtained with non-mammalian vertebrates have been interpreted in the light of those obtained with mammals. In at least one case, however, the sequence was reversed: lactogenic hormone (prolactin) was first found in birds, and subsequently in mammals!

Although it was already known from the investigations of Stricker and Grüter (1929) that in the anterior pituitary gland of mammals a substance is present which is capable of inducing lactation if the mammae are fully developed, Riddle and Braucher (1931) were the first to show that in pigeons the crop gland develops in both sexes under the influence of a hormone from the anterior pituitary; this hormone, prolactin, proved later to be responsible also for milk production in the mammalian milk gland.

Prolactin has wide-spread functions, which, so far as they are not connected with metabolism, are all related to reproduction: in addition to milk secretion in mammals, and development of the crop gland in pigeons, it causes broodiness in hens, parental care in mammals, birds and fishes, and waterdrive in newts; in birds it also plays a role in the formation of the brood-patch, and in rodents in the development of the corpus luteum of pregnancy 
from the ovulation corpus luteum; in toads the secretion of the oviducal glands is under its influence and in male mammals it is possibly also responsible for the growth and secretion of the vesicular glands.

\section{THE GONADOTROPIC FUNCTION OF THE PARS DISTALIS}

One of the greatest advances in the physiology of reproduction was the discovery of the gonadotropic function of the mammalian pituitary gland by Zondek and Aschheim (1927) and independently by P. E. Smith (1927). Thereupon it became obvious that the secretion of gonadotropic hormones in the pars distalis is impaired by the gonads, and that after castration the pars distalis produces more gonadotropic substance than under normal conditions. This again led to Moore and Price's explanation (1932) of the so-called compensatory hypertrophy of the remaining gonad following unilateral castration, and today the concept of a feedback mechanism, with which the gonads control their own secretion is well-established. Moreover, it is now generally accepted that this mechanism, though it might directly stimulate the pars distalis, generally acts indirectly on this part of the pituitary gland through the intermediation of the hypothalamus.

Although we are rather well informed about the gonadotropic influence of the pars distalis on the mammalian ovary and on ovogenesis, information about the regulation of spermatogenesis in mammals is still contradictory in many respects.

\section{REGULATION OF SPERMATOGENESIS}

It has been known for a long time that ablation of the pars distalis in male mammals results in atrophy of the testes: in most mammals the interstitial cells are impaired and all cells, with the exception of spermatogonia and Sertoli cells, disappear from the testis tubules. On the other hand, it is generally accepted that both gonadotropic hormones, follicle stimulating (FSH) and luteinization hormone (LH), play an important role in stimulating spermatogenesis in the intact animal, but it is difficult to say what particular function must be attributed to either of them.

From a long series of investigations, in which hypophysectomized rats were subsequently treated with these gonadotropins, it was concluded by Gaarenstroom and de Jongh (cf. their survey, 1946) that FSH regulates the mitotic capacity of the spermatogonia. As it was already known from the investigations of Walsh et al. (1934) and others that the degeneration of the spermatogenetic cells can be prevented, and spermatogenesis maintained by injection of normal doses of testosterone, Gaarenstroom and de Jongh, confirming this, came to the conclusion that the maintenance of spermatogenesis depends on the lengthening of the duration of life of the sperm cells (maintenance effect), and assumed that the action of FSH on the seminiferous tubules is supported by testosterone. Normal spermatogenesis in the rat is, therefore, thought to depend on FSH and on testosterone, the latter being secreted by the Leydig cells under the influence of $\mathrm{LH}$.

With this in mind, we became very much interested in studying the regulation of spermatogenesis in a cold-blooded Vertebrate with a cyclical spermatogenesis. Our work resulted in a long series of investigations on the regulation of spermatogenesis in Rana temporaria, started by Sluiter and continued by P. G. W. J. van Oordt and his collaborators. P. G. W. J. van Oordt (1956) began his investigations with a detailed description of the annual spermatogenetic cycle, which he divided into three periods, the spermiation, the spermatogenetic, and the resting periods. He then confirmed the findings of Gallien (1938) and of earlier workers in our own laboratory (Sluiter et al., 1950; G. J. van Oordt et al., 1951 ; P. G. W. J. van Oordt et al., 1952) that in the frog spermatogenesis depends largely on the gonadotropic activity of the pituitary gland, and that after hypophysectomy the primary spermatogonia lose their mitotic capacity. During the resting and spermiation periods, and during the final part of the spermatoge- 
netic period, however, neither sperm cells nor spermatogenesis are affected by hypophysectomy.

During the resting period the germinal epithelium is highly insensitive to gonadotropins, whereas during the spermiation period and the beginning of the spermatogenetic period the sensitivity is much increased. As regards the effect of environmental temperature on spermiation and spermatogenesis, van Oordt showed that this is different in different seasons, and that normal spermatogenesis can be suppressed by low temperatures, a result that he attributed to an abnormally low gonadotropic activity of the pars distalis. Additional light has no influence on spermatogenesis in the frog, and possibly in other Anura.

It was further found by van Oordt and Basu (1960) that spermatogenesis can be totally blocked in Rana temporaria, following testosterone treatment before or at the beginning of the spermatogenetic period. In Rana esculenta, van Oordt and Schouten (1961) showed in addition that testosterone retards the formation of secondary spermatogonia and thus prevents the strong increase in spermatogenetic activity which normally follows high-temperature treatment.

From his results, van Oordt concluded that the spermatogenetic cycle of Rana temporaria appears to be regulated by two cyclic factors: the environmental temperature, which determines the changes in gonadotropin secretion by the pars distalis, and the rhythmical changes in the sensitivity of the germinal epithelium to gonadotropic hormones, which is independent of the external temperature during a large part of the year. It is likely that the latter factor represents the inherent mechanism which was postulated by Witschi in 1924. [For further particulars sec van Oordt et al. (1959) and P. G. W. J. van Oordt (1960).]

\section{MECHANISM OF SPERMIATION}

Another endocrinological advance, from which comparative endocrinology has profited, was achieved when certain substances with gonadotropic functions were detected in the urine of the human female during early pregnancy. This led to the development of several procedures for diagnosing early pregnancy. One of these, the GalliMainini test (1947), has led us to carry out several purely biological investigations.

It is generally known that the GalliMainini test is based on the fact that under the influence of gonadotropic hormones the sperm cells of frogs and toads are released from the testis tubule walls, and are transported to the cloaca via the efferent testis ducts, the kidney tubules and the Wolffian duct. In 1946 van Oordt and Klomp named the sperm-release process spermiation, a word created by analogy with the term ovulation.

The spermiation process itself, that of mammals included, has not attracted much attention from a physiological point of view, and only very few investigators have dealt with it. At Cold Spring Harbor (van Oordt et al., 1959) we described how spermiation possibly took place in Rana temporaria and what the mechanism of this process might be. Since then van Dongen et al. $(1959,1960)$ have established some new facts.

In the first place it was shown that after the injection of frogs' pituitary extract the water content of the testis increases and causes a distension of the tubules. Simultaneously, the metachromatic substance, which is normally present in the lumen of the tubules along the tails of the sperm cells, disappears. Van Dongen is, therefore, of the opinion that the uptake of fluid by the testis tubules from the surrounding blood vessels is the result of a depolymerization of an acid mucopolysaccharide by which the colloid osmotic value of the testis tubules is increased.

Because the tubules are closed at one end and communicate with the efferent duct system only by very narrow canals, the testis tubules may be regarded as a nearly closed systerm. Now the walls of these tubules contain elastic fibers (van Dongen, Draisma, and de Kort, 1959) ; consequently the elasticity of the tubule wall gives rise to an increasing counterpressure on its con- 
tent, followed by a considerable discharge of fluid from the tubules. The sperm bundles, which are connected with the Sertoli cells and are situated almost perpendicularly to the tubule wall, will be loosened from the Sertoli cells by this fluid stream, and will then be carried away passively into the direction of the efferent ducts. The acid mucopolysaccharide concerned is thought to be hyaluronic acid.

Spermiation, therefore, is possibly initiated by depolymerization of hyaluronic acid into its constituent elements, the latter process being followed by an uptake of fluid into the testis tubules from the surrounding blood capillaries. It is thought that under natural conditions the break down of hyaluronic acid takes place under the action of hyaluronidase, and that this process is regulated by a hypophyseal hormone.

\section{FUNCTION OF THE VARIOUS CELL TYPES OF THE PARS DISTALIS}

Especially after World War II, endocrinologists became very interested in establishing the functions of the various cell types of the pars distalis. To my regret I am not able to treat this problem fully. There are still so many controversies, and the nomenclatures used are so different from each other, that it is usually very difficult to compare the various results. Moreover, it is questionable whether we are justified in attributing to a certain cell type of the pars distalis in an amphibian the same endocrine function as is attributed to an apparently similar cell type in a mammal!

In our laboratory, P. G. W. J. van Oordt has started an investigation of this problem in the common frog, Rana temporaria (van Oordt, 1961), and has concluded that the formation of a gonadotropic hormone, probably $\mathbf{F S H}$, is to be ascribed to an amphiphilic $\beta$-cell. Similar cells were also observed in the pars distalis of Bufo bufo and of Xenopus. Further investigations into this subject will be carried out.

\section{INFLUENCE OF LIGHT}

It has been known for a long time that environmental factors, such as light, tem- perature, rainfall and diet, are of primary importance in determining certain reproductive phenomena.

Here we will especially draw attention to the epoch-making investigations of Rowan (1926-1929), who submitted juncos (Junco hyemalis) during late autumn and winter, when their gonads are minute, to ever increasing installments of light by adding several hours of artificial illumination to the natural winter day-length. He was thus able to induce in his male birds a pronounced precocious development of the testes, together with intense spermatogenesis, exactly comparable to the same phenomena that occur normally in hirds during spring.

Some years later Burger $(1939,1940)$ stressed the fact that it is not actually the increasing light in spring that is the cause of the gonad recrudescence, but that the gonads begin to increase in size and function when in spring a certain quantity of light per day is available; in addition, the intensity of illumination is a factor of importance.

Numerous species of birds (and also of mammals) have been subjected to increasing dosages of daily illumination, to light of different wave lengths, and of different intensities, and so forth (cf. Bissonnette, 1932; Benoit, 1936, 1937; cf. also Burger's review, 1949). All these investigations demonstrated the great importance of light as a regulating factor of the sexual cycle in male birds. In female birds it was found, however, that the factors inducing gonadal maturity are much more complex.

It is, therefore, generally accepted nowadays that photostimulation in spring is the principal factor inducing spermatogenesis in birds. From Rowan's experiments it is apparent that the increasing temperature in spring plays no role, for his birds became fully mature notwithstanding the fact that they were kept in the open at extreme low temperatures of from $-20^{\circ} \mathrm{C}$ to $-45^{\circ} \mathrm{C}$ !

One of the most interesting discoveries made in connection with Rowan's experiments was the finding that the avian testis is refractory to light during a certain period after the breeding season.

In post-war years the refractorincss to 
light has been the subject of many investigations. It has been shown amongst others by Miller (1948), Wolfson (1952, 1959), and Laws (1961) that in song-birds this phase always originates after a period of gonadal activity, and that during the refractory period gonadal development cannot be initiated by increased artificial illumination. It is evident, therefore, that the gonads require a period of rest and inactivity before resuming breeding activities.

Neither the site nor the cause of refractoriness are known. All we can say is that the hypothalamus might be the site of refractoriness as Farner and his co-workers (cf. Farner, 1962) have found that during the refractory period a great deal of neurosecretory material is stored in the hypothalamus.

We can conclude this section with the statement that the refractory period is a very advantageous phenomenon, since it prevents the continuation of the breeding condition during the latter part of summer and during the first autumn months, when the total amount of light would itself still be sufficient to induce gonadal maturity.

Our laboratory has contributed only one investigation into the influence of light on the testes of birds. This was a scientific repetition of a traditional procedure applied formerly in the Netherlands by local bird catchers to obtain in autumn, live, singing, male song-birds as decoys. It was customary to put these birds gradually into the dark at the beginning of May and then little by little to expose them to light again in August, with the result that during September and October they were in full song and then were exceptionally suitable as decoys. It is also known that in Japan the practice of "yogai" is in vogue; this consists of exposing cage-birds (whiteeyes) to artificially increased photostimulation towards the close of the year in order to bring them into singing condition in January.

Damsté (1947) encaged male greenfinches (Chloris chloris) early in May, and reduced the daylight in the cages progressively during the course of that month. The birds were kept in the dark during June,
July, and the first half of August. From the middle of August until the end of this month daylight was gradually admitted again, and in the beginning of September the birds were in full song for the second time. In the middle of October, after some weeks of sperm production, testis regression set in. Subsequently his birds were exposed to increasing electric light from the beginning of December onwards, with the result that in January they possessed enlarged testes with sperm-formation, while at the end of that month they were again in full song. It is, therefore, possible to bring song-birds into breeding condition three times within twelve months by subjecting them to alternate periods of darkness and light. According to Wolfson (1954) it is even possible to induce a breeding condition in song-birds as often as five times in the course of one year by suitable manipulations.

There is still another interesting problem with regard to the influence of light on birds.

During the autumn migration countless birds belonging to many palae- and nearctic species migrate thousands of miles beyond the equator. In the southern parts of all large continents (South Africa, South America, Australia) thousands of birds which have bred in the northern parts of Eurasia and of North America arrive there to take advantage of the southern spring.

When during our autumn these birds have crossed the equator, they come into countries in which the daylight is lengthening instead of shortening. In the tropical zone this change of day length is not very pronounced, but from the Tropic of Capricorn southward the days lengthen considerably until about the beginning of December. Thus, after having crossed the equator, these birds come into areas in which nature provides the best cxpcrimental conditions possible with respect to increasing periods of daily illumination, but their reproductive organs do not react and they do not breed there!

The question, why northern birds, wintering south of the Tropic of Capricorn, do not react to increasing light during their stay in these southern areas, may perhaps 
be answered by the following hypotheses (G. J. van Oordt, 1959) : either these birds do not react to light at all, because their periodical reproductive functions are regulated by an internal, inherent rhythm, or they are refractory to increasing light during a period which is so much protracted (Farner, 1954; Marshall, 1955) that it ends at approximately the time when in the southern hemisphere the days begin to wane. In the latter case their gonads will not be stimulated before these migrants have crossed the Tropic of Cancer on their northward flight.

\section{THE PATHWAY OF THE LIGHT STIMULUS}

It goes without saying that the pathway along which the light stimulus is conducted in the body has been studied by many investigators. The most detailed work with respect to this has been carried out by Benoit and his associates. Before dealing with this problem we have, however, to mention the concepts of neurosecretion and of the hypothalamo-pituitary-gonad axis which have enormously broadened our view on many fundamental endocrinological problems.

More than 30 years ago E. Scharrer (1928) described the presence of neurosecretory cells in the hypothalamus of the teleost Phoxinus phoxinus. In the hypothalamus of mammals and birds similar cells are collected into two nuclei on each side (the $n$. paraventricularis and the $n$. supraopticus) whereas in Anamnia these are represented by only one nucleus on each side, the $n$. praeopticus.

In 1953 Hild and Zetler found that after sectioning the hypophyseal tract, which consists of axons originating from cells in the nuclei mentioned, neurosecretory material accumulated at the hypothalamic side of the section; thus they showed that the neurosecretory material which was found in the cell bodies as well as in these axons moved from the cell body to the neurohypophysis. The theory that the neurohypophyseal hormones are formed and secreted by the pituicytes in the neurohypophysis had, therefore, to be abandoned, and to be replaced by the theory that the hormones vasopressin and oxytocin, or their prohormones, are present in the neurosecretorial material, which is formed in the hypothalamic nuclei. Thus in the neurohypophysis the pituicytes play only a subordinate role.

As regards the anterior pituitary, this is connected with the hypothalamus by the hypophyseal portal system (Popa and Fielding, 1930), in which the blood circulates from the median eminence to the anterior pituitary (Green and Harris, 1949); in mammals short capillary loops are closely related to the distal ends of hypothalamic axons, whereas in birds this relationship is brought about through axonloops running to the portal vessels (cf. Scharrer and Scharrer, 1954).

It is now generally accepted that three different releasing factors are transported from three different areas in the hypothalamus to the anterior pituitary, and that in the anterior pituitary these releasers stimulate specific cells to produce and release thyrotropic, adrenalcorticotropic and gonadotropic hormones, respectively. The nature of these releasers, however, is not yet fully known.

In 1936 and 1937 Benoit found, by wrapping juvenile ducks in black sacks, with or without eyeholes, and then illuminating them, that the light stimulates the retina, and that the stimulus is conducted from the retina via the optic nerve to the hypothalamus; moreover, Benoit (1938) demonstrated by means of a quartz rod fixed in the empty orbit of a duck that light can also stimulate the hypothalamus directly.

It is, therefore, obvious that under natural conditions the light stimulus induces the hypothalamus to secrete its gonadotropic hormone releaser. As it was further shown that the pars distalis could no longer be stimulated by light after sectioning either of the median eminence near the optic chiasma or of the anterior part of the hypophyseal portal vessels (Benoit and Assenmacher, 1959; Benoit, 1962) it is evident that this releaser must be transmitted through the portal vessels to the pars distalis, which then in turn is stimulated to secrete its gonadotropic hormones. 
Finally I will cite Benoit's statement that according to experiments in which immature ducks were kept in darkness "light is not a necessary stimulus for the complete development of the duck's testis. But, when present, light enhances this development" (Benoit, 1955, p. 92).

Herewith I will conclude my survey in which I have described some investigations into the comparative endocrinology of reproduction, carried out in my laboratory. I hope to have succeeded in treating them against the background of what are in my opinion the more spectacular advances in reproductive endocrinology during the past 50 years. These discoveries were not only the origin of a wealth of new information, they gave also rise to our own work. I, therefore, should like to express here my gratitude for the privilege my co-workers and I have had in adding some new facts to this most interesting field of research. I should like also to thank the organizers of this Conference for giving me the opportunity to read this opening address, which in this year of my retirement is in some respect also a farewell lecture.

When opening the First Symposium on the Comparative Endocrinology of Vertebrates in Liverpool in 1954 Professor Pumphrey thought that that Symposium promised "to be the dawn of a new day for comparative endocrinology in England."

Now, eight years later, I can state that the recent development of our science in Britain and on the Continent has justified his prediction; indeed, I am even of the opinion that a bright sun is now shining over that new day of comparative endocrinology. In the confident expectation that the forthcoming three days will also stand in the luster of the rays of this sun, I now open the first Conference of European Comparative Endocrinologists.

\section{REFERENCES}

Allen, E., ANd Doisy, E. A. (1923). An ovarian hormone: A preliminary report on its localization, extraction and partial purification, and action in test animals. J. Am. Med. Assoc. 81, 819 .
Benoit, J. (1923). Transformation expérimentale par ovariotomie précoce chez la poule domestique. Compt. rend. acad. sci. 177, 1074.

Benoit, J. (1936). Facteurs externes et internes de l'activité sexuelle. I. Stimulation par la lumière de l'activité sexuelle chez le canard et la cane domestiques. Bull. biol. France el Belg. 70, 487-533.

BenoIT, J. (1937). Facteurs externes et internes de l'activité sexuelle. II. Étude du mécanisme de la stimulation par la lumière de l'activité testiculaire chez le canard domestique. Rôle de l'hypophyse. Bull. biol. France et Belg. 71, 394-437.

BenoIT, J. (1938). Actions de divers éclairements localisés dans la région orbitaire sur la gonadostimulation chez le canard mâle impubère. Croissance testiculaire provoquée par l'éclairement indirect de la région hypophysaire. Compt. rend. soc. biol. 127, 909.

Benoit, J. (1955), In "Discussion of A. J. MarshALL's Reproduction in male birds." Mem. Soc. Endocrinol. 4, 89-93.

Benort, J. (1962). Hypothalamo-hypophyseal control of the sexual activity in birds. Gen. and Comp. Endocrinol. 1, Suppl. 1, 254-274.

Benoit, J., and Assen macher, I. (1959). The control of visible radiations of the gonadotropic activity of the duck hypophysis. Recent Progr. in Hormone Research 15, 143-164.

Berthold, A. A. (1849). Transplantation der Hoden. Arch. Anat., Physiol. und wiss Med., $42-46$.

Bissonnetre, T. H. (1932). Studies on the sexual cycle in birds. VI. Effects of white, green and red lights of equal luminous intensity on the testis activity of the European Starling (Stumus vulgaris). Physiol. Zool. 5, 92-123.

Bouin, P., ANd ANcel, P. (1903). Recherches sur les cellules interstitielles du testicule chez les mammifères. Arch. zool. exptl. et gén., qe Sér. $1,437-520$.

Bretschneider, L. H., and Duyvené de Wit, J. J. (1941). Histophysiologische Analyse der sexuellendokrinen Organisation des Bitterlingweibchens (Rhodeus amarus). Z. Zellforsch. mikroskop. Anat. 31, 227-344.

Burger, J. W. (1939). Some aspects of the roles of light intensity and the daily length of exposure to light to the sexual photoperiodic activation of the male starling. J. Exptl. Zool. 81, 333-341.

Burger, J. W. (1940). Further studies on the relation of the daily exposure to light to the sexual activation of the male Starling (Stumus vulgaris). J. Exptl. Zool. 84, 351-361.

Burger, J. (1949). A review of experimental in- 
vestigations on seasonal reproduction in birds. Wilson Bull. 61, 211-230.

Burns, R. K. (1925). The sex of parabiotic twins in Amblystoma. J. Exptl. Zool. 42, 31-89.

Burrs, R. K. (1930). The process of sex transformation in parabiotic Amblystoma. 1. Transformation from female to male. J. Exptl. Zool. 55, 123-129.

Burns, R. K. (1931). The process of sex transformation in parabiotic Amblystoma. II. Transformation from male to female. J. Exptl. Zool. 60, 339-389.

Corner, G. W., and Allen, W. M. (1929). Physiology of the corpus luteum. II. Production of a special uterine reaction (progestational proliferation) by extracts of the corpus luteum. $A m$. J. Physiol. 88, 326.

Chew, F. A. E. (1923). Studies in intersexuality. II. Sex reversal in the fowl. Proc. Roy. Soc. B95, 265-278.

Damsté, P. H. (1947). Experimental modification of the sexual cycle of the greenfinch. J. Exptl. Biol. 24, 20-35.

D'Ancona, U. (1950). Détermination et différenciation du sexe chez les poissons. Arch. anat. microscop. morphol. exptl. 39, 274-294.

DantschakofF, V. (1941). "Der Aufbau des Geschlechts beim höheren Wirbeltier." G. Fischer, Jena.

David, K., Dingemange, E., Freun, J., and LaQUER, E. (1935). Über krystallinisches männliches Hormon aus Hoden (Testosteron) wirksamer als aus Harn oder aus Cholesteron bereitetes Androsteron. Z. physiol. Chem. 233, 281.

Domm, L. V. (1927). New experiments on ovariotomy and the problem of sex inversion in the fowl. J. Exptl. Zool. 48, 31-173.

Dомм, L. V. (1931). A demonstration of equivalent potencies of right and left testis-like gonads in the ovariectomized fowl. Anat. Record 49, 211-249.

FArNER, D. S. (1954). Northward transequatorial migration of birds. New Zealand Science Rev. 12, 29-30.

FarNer, D. S. (1962). Hypothalamic neurosecretion and phosphatase activity in relation to the photoperiodic control of the testicular cycle of Zonotrichia leucophrys Gambelii. Gen. and Comp. Endocrinol. 1, Suppl. 1, 160-167.

Freud, J., de Fremery, P., and Laqueur, E. (1932). Eichung des "männlichen" Hormons mit Hilfe der Kammwachstumsreaktion. Pfü̈ger's Arch. ges. Physiol. 229, 763-786.

GaArenstroom, J. H., AND DE Jongh, S. E. (1946). "A Contribution to the Knowledge of the In- fluence of Gonadotropic and Sex Hormones on the Gonads of Rats." Elsevier, Amsterdam.

Gallacher, T. F., and Косh, F. C. (1930). The quantitative assay for the testicular hormone by the comb growth reaction. J. Pharmacol. and Exptl. Therapy 40, 327 .

Gallien, L. (1938). Inhibition du cycle sexuel et involution testiculaire consécutives à l'hypophysectomie chez Rana temporaria L. Compt. rend. soc. biol. 129, 1043.

GaLLien, I. (1955). The action of sex hormones on the development of sex in Amphibia. Mem. Soc. Endocrinol. 4, 188-204.

Gallies, L. (1956). Inversion expérimentale du sexc chez un Anoure inférieur, Xenopus laevis Daudin. Analyse des conséquences génétiques. Bull. biol. France et Belg. 90, 163-183.

Galli-Mainini, C. (1947). Pregnancy test using the male toad. J. Clin. Endocrinol. 7, 653.

Green, J. D., ANd Harris, G. W. (1948). Observation of the hypophysioportal vessels of the living rat. J. Physiol. 108, 359-361.

HaRMS, J. W. (1923). Untersuchungen über das Biddersche Organ der männlichen und weiblichen Kröten. II. Mitt. Die Phvsiologie des Bidderschen Organs und die experimentellphysiologische Umdifferenzierung vom Männchen in Weibchen. Z. Anat. Entwicklungsgeschichte 69, 598-629.

Hild, W., aNd ZetLer, G. (1953). Experimenteller Beweis für die Entstehung der sog. Hypophysenhinterlappenwirkstoffen im Hypothalamus. Pfiuger's Arch. ges. Physiol. 257, 169-201.

HoAk, W. S. (1955). Reproduction in teleost fishes. Mem. Soc. Endocrinol. 4, 5-24.

Humphrey, R. R. (1928). The developmental potencies of the intermediate mesoderm of Amblystoma when transplanted into ventrolateral sites in other embryos: the primordial germ cells of such grafts and their role in the development of a gonad. Anat. Record 40,67101 .

HUMphrey, R. R. (1936). Studies on sex reversal in Amblystoma. IX. Reversal of ovaries to testes in parabiotic A. tigrinum. J. Exptl. Zool. $73,1-21$.

Josт, A. (1947). Recherehes sur la différentiation sexuelle de l'embryon de lapin. I. Introduction et embryologie génitale normale. Arch. anat. microscop. morphol. exptl. 36, 151-200. II. Action des androgènes de synthèse sur l'histogénèse génitale. Ibidem, 36, 242-270. III. Rôle des gonades foetales dans la différentiation sexuelle somatique. Ibidem, 36, 271-315.

Jost, A. (1961). The role of fetal hormones in prenatal development. Harey Lectures, Ser. $55,201-226$ 
Kéler, K., and Tandler, J. (1916). Ueber das Verhalten der Eihäute bei der Zwillingsträchtigkeit des Rindes. Untersuchungen über die Entstehungsursache der geschlechtlichen Unterentwicklung von weiblichen Zwillingskälbern, welche neben einem männlichen Kalbe zur Entwicklung gelangen. Wiener tierärztl. Wochschr. 3, 513-526.

LAws, D. F. (1961). Hypothalamic neurosecretion in the refractory and post-refractory periods and its relationship to the rate of photoperiodically induced testicular growth in Zonotrichia leucophrys Gambelii. Z. Zellforsch. 54, 276-306.

LiLLIE, F. R. (1916). The theory of the freemartin. Science 43, 611-613.

LILLIE, F. R. (1917). The free-martin, a study of the action of sex hormones in the foetal life of cattle. J. Exptl. Zool. 23, 371-452.

Lipschürz, A. (1919). "Die Pubertätsdrüse und ihre Wirkungen." Bern.

Marshall, A. J. (1955). Reproduction in male birds. Mem. Soc. Endocrinol. 4, 75-93.

Miller, A. H. (1948). The refractory period in light-induced reproductive development of golden-crowned sparrows. J. Exptl. Zool. 109, 1-11.

Moore, C. R. (1943). Sexual differentiation in the opossum after early gonadectomy. J. Exptl. Zool. 94, 415-461.

Moone, C. R. (1947). "Embryonic Sex Hormones and Sexual Differentiation." C. C Thomas, Springfield, Illinois.

Moore, C. R., and Price, D. (1932). Gonad hormone functions, and the reciprocal influence between gonads and hypophysis with its bearing on the problem of sex-hormone antagonism. Am. J. Anat. 50, 13-71.

NoBle, G. K., AND WurM, M. (1940). The effect of hormones on the breeding of the laughing gull. Anat. Record 78, Suppl., 50.

Nussbaum, M. (1909). Hoden und Brunstorgane des braunen Landfrosehes. Pfïger's Arch. ges. Physiol. 126, 519-577.

Pézard, A. (1912). Sur la détermination des caractères sexuels secondaires chez le Gallinacés. Compt. rend. acad. sci. 154, 1183.

PÉzard, A. (1918). Le conditionnement physiologique des caractères sexuels secondaires chez les oiseaux. Du rôle endocrine des glandes génitales. Bull. Biol. 52, 1.

Pézard, A., Sand K., and Caridroit, F. (1926). Les hormones sexuelles et le gynandromorphisme chez les Gallinacés. Arch. Biol. 36, 541.

Ponse, K. (1924). L'organe de Bidder et le déterminisme des caractères sexuels secondaires du crapaud (Bufo vulgaris L.). Rev. suisse Zool. 31, 177-336.

Popa, G. T., and Fielding, U. (1930). A portal circulation from the pituitary to the hypothalamic region. J. Anat. 65, 88-91.

Riddle, O., ANd Bratcher, P. F. (1931). Studies on the physiology of reproduction in birds. XXX. Control of the special secretion of the crop-gland in pigeons by an anterior pituitary hormone. Am. J. Physiol. 97, 617-625.

RoWan, W. (1926). On photoperiodism, reproductive periodicity and the annual migrations of birds and certain fishes. Proc. Boston Soc. Natl. Hist. 38, 147-189.

Rowan, W. (1929). Experiments in bird migration. I. Manipulation of the reproductive cycle: seasonal histological changes in the gonads. Proc. Boston Soc. Natl. Hist. 39, 151-208.

Scharrer, E. (1928). Die Lichtempfindlichkeit blinder Elritzen. Untersuchung über das Zwischenhirn der Fische. I. Z. vergleich. Physiol. 7, 1-38.

Scharrer, E., and Scharrer, B. (1954). Hormones produced by neurosecretory cells. Recent Progr. in Hormone Research 10, 183-240.

Sluiter, J. W. (1945). Experimentelle Untersuchungen über die Funktion des Interstitiums der Gonade. I. Versuche an männlichen und weiblichen juvenilen Mäusen. Z. Zellforsch. 33, 311-335.

Slumer, J. W., and Van Oordt, G. J. (1947). Experimental data on the function of the interstitium of the gonads: experiments with cockerels. Quart. J. Microscop. Sci. 88, 135-150.

Slutter, J. W., ANd Van Oordt, G. J. (1949). The influence of a gonadotrophin on the seasonal changes in the testis and deferent duct of the Chaffinch (Fringilla coelebs). Quart. J. Microscop. Sci. 90, 1-11.

Sluiter, J. W., Van Oordt, G. J., and Grasveld, M. S. (1950). Spermatogenesis in normal and hypophysectomized frogs (Rana temporaria) following gonadotrophin administration. I. Experiments with spring and summer frogs. Acta Endocrinol. 4, 1-15.

Smiтh, P. E. (1927). The introduction of precocious sexual maturity by pituitary homeotransplants. Am. J. Physiol. 80, 114.

Steinach, E. (1894). Untersuchungen zur vergleichenden Physiologie der männlichen Geschlechtsorgane insbesonders der accessorischen Geschlechtsdrüsen. Pfiüger's Arch. ges. Physiol. 56, 304-338.

Steinach, E. (1910). Geschlechtstrieb und echt sekundäre Geschlechtsmerkmale als Folge der innersekretorischen Funktion der Keimdrüsen. 
II: Uber die Entstehung des Umklammerungsreflexes bei Frosehen. Zentr. Physiol. 24, 551. Steinach, E. (1912). Willkürliche Umwandlung von Säugetiermännchen in Tiere mit ausgeprägt weiblichen Geschlechtscharakteren und weiblicher Psyche. Eine Untersuchung über die Funktion und Bedeutung der Pubertätsdrüisen. Pfluger's Arch. ges. Physiol. 144, 71-108.

Steinach, E. (1913). Feminierung von Männchen und Maskulierung ron Weibchen. Zentr. Physiol. 27, 717.

Streve, H. (1921). Entwicklung, Bau und Bedeutung der Keimdrüsenzwischenzellen. Ergeb. Anat. u. Entwicklungsgeschichte 23, 1-249.

Stockard, C. R., axd Papanicolaou, G. N. (1917). The existence of a typical oestrous cycle in the guinea pig with a study of its histological and physiological changes. Am. J. Anat. 22, 225-283.

Stricker, P., AND Grüter, F. (1929). Uther die Wirkung eines Hypophysenvorderlappenhormons auf die Auslösung der Milchsekretion. Klin. Wochschr. 8, 2322.

Van Dongen, W. J., Axo de Ковт, E. J. M. (1959). Spermiation in the common frog (Rana temporaria). I. Experiments on the isolated testis. Proc. Koninkl. Ned. Akad. Wetenschap. Ser. C, 62, 320-326.

Van Dongen, W. J., Draisma, J. R., and de Kort, E. J. M. (1959). Spermiation in the common frog (Rana temporaria). II. Experiments in vivo. Proc. Koninkl. Ned. Akad. Wetenschap., Ser. C, 62, 327-332.

Van Dongen, W. J., Ballieux, R. E., Geursen, H. J., ANd Offermans, T. (1960). Spermiation in the common frog (Rana temporaria). III. Histochemical and chemical investigations. Proc. Koninkl. Ned. Akad. Wetenschap., Ser. $C, 63,257-263$.

VAN OORDT, G. J. (1924). Die Veränderungen des Hodens während des Auftretens der sekundären Geschlechtsmerkmale bei Fischen. I. Gasterosteus pungitius L. Arch. mikrosk. Anat. Entwicklungsmech. 102, 379-405.

VAN Ооврт, G. J. (1925). The relation between the development of the secondary sex characters and the structure of the testis in the teleost Xiphophorus helleri Heckel. Brit. J. Exptl. Biol. 3, 43-59.

VAN OoRDT, G. J. (1933). Weitere Untersuchungen über den Einfluss der Geschlechtshormone auf die sckundären Gesehlechtsmerkmale des Truthuhns. Ovariektomie der Truthenne. Roux' Arch. Entwicklangsmech. 130, 11-18.

VAN OORDT, G. J. (1959). The reaction of the gonads to lengthening days in northern birds, migrating far beyond the equator. Proc. First
Pan-African Omithol. Congr. Ostrich, Suppl. 3, $342-345$

Van Oondt, G. J., aNd Junge, G. C. A. (1933). Die hormonale Wirkung der Gonaden auf sommer- und Prachtkleid. I. Der Einfluss der Kastration bei männlichen Lachmöwen (Larus ridibundus L.). Roux' Arch. Entwicklungsmech. $128,166-180$.

Van Oordt, G. J., and Junge, G. C. A. (1936). Die hormonale Wirkung der Gonaden auf Sommer- und Prachtkleid. III, Der Einfluss der Kastration auf männliche Kampfläufer (Philomachus pugnax). Roux' Arch. Entwicklingsmech. 134, 112-121.

Van Oordt, G. J., and Klomp, H. (1946). Effects of oestrone and gonadotrophin administration in the male toad (Bufo bufo). Proc. Koninkl. Ned. Akad. Wetenschap. 49, 565-570.

VAN OoRdt, G. J., ANd Rinkel, G. L. (1940). Der Einfluss von Geschlechtshormonen insbesondere von Dehydroandrosteron auf die Gonadenentwicklung von Hühnerembryonen. Roux' Arch. Ertwicklungsmech. 140, 59-80.

Van Oofdt, G. J., and Van der Maas, C. J. J. (1929). Kastrationsversuche am Truthahn. Roux' Arch. Ertuicklungsmech. 115, 651-667.

VAN OORDT, G. J., VAN OORDT, P. G. W. J., AND $V_{\text {AN DN DoN }}$ W. J. (1959). Recent experiments on the regulation of spermatogenesis and the mechanism of spermiation in the Common Frog, Rana temporaria. In "Comparative Endocrinology," pp. 488-498. Wiley, New York.

Van OORdt, G. J., Sluiter, J. W., and Van OORdt, P. G. W. J. (1951). Spermatogenesis in normal and hypophysectomized frogs (Rana temporaria) following gonadotrophin administration. Acta Endocrinol. 7, 257-269.

VAN OoRDT, P. G. W. J. (1956). Regulation of the spermatogenetic cycle in the Common Frog (Rana temporaria). Thesis, Utrecht.

Vax OoRd, P. G. W. J. (1960). The influence of internal and external factors in the regulation of the spermatogenetic cycle in Amphibia. Symp. Zool. Soc. Lond. 2, 29-52.

VAN OoRDr, P. G. W. J. (1961). The gonadotropinproducing and other cell types in the distal lobe of the pituitary of the common frog, Rana temporaria. Gen. and Comp. Endocrinol. 1, 364374.

Van Oordt, P. G. W. J., and Basu, S. L. (1960). The effect of testosterone on the spermatogenesis of the common frog, Rana temporaria. Acta Endocrinol. 33, 103-110.

Van Oordt, P. G. W. J., And Schouten, S. C. M. (1961). Effect of testosterone on spermatogenesis of the edible frog Rana esculenta. J. Reprod. Fertil. 2, 61-67. 
VAN Oordt, P. G. W. J., Sluiter, J. W., and VAN OondT, G. J. (1952). Spermatogenesis in normal and hypophysectomized frogs (Rana temporaria) following gonadotrophin administration. III. Injection of summer pituitary extract in winter frogs. Acta Endocrinol. 9, 155-160.

Walsh, E. L., Cuyler, W. K., axo McCullagh, D. R. (1934). Physiologic maintenancy of male sex glands; effect of androtin on hypophysectomized rats. Am. J. Physiol. 107, 508-512.

Wells, L. J. (1959). Functioning of the anterior hypophysis in the fetal rat. In "Comparative Endocrinology," pp. 444-451. Wiley, New York.

Willier, B. H. (1921). Structures and homologies of free-martin gonads. J. Exptl. Lool. 33, 63127.

Willier, B. H., Gallacher, T. F., ANd Koch, F. C. (1935). Sex-modification in the chick embryo resulting from injection of male and female hormones. Proc. Natl. Acad. Sci. 21, 625-631.

Witschi, E. (1924). Die Entwicklung der heimzellen der Rana temporaria L. Erster Teil: Urkeimzelle und Spermatogenesis, Z. Zelljorsch. Gewebelehre 1, 523-561.

Witschi, E. (1927). Sex-reversal in parabiotic twins of the Amcrican wood-frog. Biol. Bull. 52, 137-146.

Witschi, E. (1936). Studies on sex differentiation and sex determination in Amphibians. VIII.
Experiments on inductive inhibition of sex differentiation in parabiotic twins of Salamanders. Anat. Record 66, 483-503.

Wolff, E., ANd Ginglinger, A. (1935). Sur la transformation des poulets males en intersexués par injection d'hormone femelle (folliculine) aux embryons. Arch. Anat. Histol. Embryol. 20, 219-278.

Wolfson, A. (1952). The occurrence and regulation of the refractory period in the gonadal and fat cycle of the Junco. J. Exptl. Zool. 121, 311-326.

Wolfson, A. (1954), Production of repeated gonadal, fat and molt cycles within one year in the junco and white-crowned sparrow by manipulation of day length. J. Exptl. Zool. 125, 353-376.

Wolfson, A. (1959). Role of light and darkness in regulation of refractory period in the gonadal and fat cycles of migratory birds. Physiol. Zool. 32, 160-176.

Zawadowsky, M. M. (1922). "Das Geschlecht und die Entwicklung der Geschlechtsmerkmale." Moseow.

Zawadowsky, M. M. (1926). Bisexual nature of the hen and experimental hermaphroditism in hens. Trans. Lab. Exptl. Biol. 2, 164. 179.

ZovdeK, B., ANd AschHeim, S. (1927). Hypophysenworderlappen und Ovarium. Arch. Gynäkol. 130,1 . 